\title{
The Travel Advisory as an Obstacle to Travel and Tourism. Case Study-The Greek Economic Crisis
}

\author{
Dr. Dimitrios Mylonopoulos \\ Professor, Piraeus University of Applied Sciences \\ dimilon@teipir.gr \\ Dr. Polyxeni Moira * \\ Professor, Piraeus University of Applied Sciences \\ polmoira@teipir.gr

\section{Dr. Aristidis Papagrigoriou} \\ Lecturer, Piraeus University of Applied Sciences \\ apapagregg@yahoo.gr
}

\begin{abstract}
Tourist activity is strongly influenced by a number of unpredictable factors and imponderables, like terrorist actions, armed conflicts - warfare, epidemics, natural disasters etc. The negative atmosphere often deteriorates by travel advisories issued after important incidents (terrorist attacks, natural disasters, epidemics, political instability etc.) and lead to the limit or the pause of the tourist flows. The travel advisories are usually issued by states, as well as by international organizations, in the case that an incident relates to them. Such an example is the World Health Organization in the event of an epidemic or pandemic (SARS, MERS etc.).

Travel advisories aim to the travelers' protection from serious dangers. Often, though, the travel advisories tend to overemphasize the existing danger and function as a means of exerting pressure from one state to another, in order to attain a desired effect. The impact of the travel advisories on a country's or a broader region's tourism is intensified by the way the former is presented by the media at local and international level.

In any case, due to the enormous economic and social effects of the travel advisories on the country they refer to, their plausible issue by the states is imperative. Apart from that, their rational management by the statesreceivers, as well as by the tourism policy bodies is also absolutely necessary, so that all their adverse affects are minimized and the free movement of the travelers is not blocked, as is contemplated by International Treaties and Declarations.
\end{abstract}

Keywords: Travel advisory, travel advice, travel warning, tourism, ethics

\section{INTRODUCTION}

In this age and date travel is an important activity of everyday life. It brings people a note of contentment as it gives them the chance to satisfy their needs for leisure, recreation, contact with other nations and lifestyles, escape from the everyday life etc. (Mathieson \& Wall, 1982) while, at the same time, it facilitates the international empathy among nations (UNWTO, 2007).

Tourism, as a leisure time activity, is, with no doubt, the predominant form of recreation in the $21^{\text {st }}$ century. According to the World Travel and Tourism Council/WTTC data (2015:1) in 2014 travelling and tourism directly supported 105.408 .000 jobs, that is $3.6 \%$ of total jobs and totally 276.845 .000 jobs $(9.4 \%$ of the total).

Tourism is undoubtedly related to politics. As a matter of fact, this association is complicated. Tourism's development and promotion at local, regional, national or international level is related to the country's broader economic and social policy, while it is obvious that the public tourism policy reflects or is conducted by each government's or administrative body's ideology and targets. Of course, most of the countries seek for tourism development, since the latter contributes to the economic, political, social and cultural development, as well as to the economy's differentiation.

However, the link between politics and tourism is not always positive, that is within the meaning of the intervention needed to facilitate tourism development. So, the states often impose direct or indirect restrictions on tourist flows. Such restrictions may refer to limits of the amount of money a tourist is entitled to carry, strict prerequisites or time limits concerning the visas' issue, limits of the number of 
the incoming tourists etc. Furthermore, a country's or a region's political situation alone can have a negative impact on tourism.

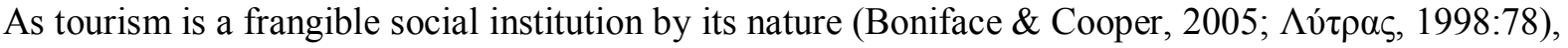
it is significantly influenced by unpredictable factors and imponderables, like the political instability, the onset of a terrorist act, an epidemic, a natural disaster etc. The extent to which this phenomena affect the tourist flows of the country within which the events occurred, exacerbates by the way that these events are presented by the media at local and international level, namely at the tourists' place of origin as well as at their host regions. The negative atmosphere deteriorates due to the travel advisories that go with such phenomena and often cause the pause of the tourist flows in these regions

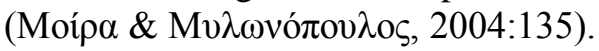

\section{THE TRAVEL ADVISORY}

The states, in order to inform their citizens about a country's situation, they operate a website, which provides information and advices concerning each country. These information initially refer to the destination's description (geographical features, map, climate, area, population, currency, language etc.) but, then, they extend to features relevant to the prerequisites and the way that travel documents are issued in order to enter the country, they notice special provisions and information regarding the applicable law in matters such as the smuggling of products, drunkenness, speeding etc, as well as the ways to move within the country. However, the advices concerning safety issues and issues relevant to the travelers' health are of great importance. The USA, Canada, Australia, New Zealand, Great Britain, France, Italy, Poland and other countries retain such websites.

Apart from the operation of such websites, the states often issue travel advisories in the case that events that can significantly affect the travelers' lives arise. According to the British Dictionary (2015) "travel advisories are issued by a governmental or an international body (like the UNO) that draws the travelers' attention to concrete destinations for a number of reasons, like armed violence, popular revolutions or political unrest, high crime rates (particularly abductions or/and crimes), natural disasters or outbreaks of contagious diseases".

The term alone reveals a lot of problems, since in the tourism sector the terms travel advice, travel advisory, travel warning and travel alert are used, but not with the same meaning. Accordingly, there are not uniform levels of the guidelines. So, the advisory's level extends from simply preventive, for example an advice that refers to simple safety-related measures that every person away from its residence complies with, to advices for a trip's cancellation.

The travel advisories are, most of the times, issued by the states and addressed to the citizens who intend to travel or already are abroad. The travel advisories' issue is supposed to be the states' obligation (Dupont \& Steffen, 1997; Zuckerman, 2001; WHO, 2003) and is performed by the competent Ministry, which usually is the Ministry of Foreign Affairs, but without excluding the intervention of the Ministry of Health ${ }^{1}$ or the Ministry of Tourism. However, the travel advisories' issue is not only a privilege of the states. Often, travel advisories are also issued by other bodies. So, apart from the advisories of state origin, there also are those of trans-national origin, for example the ones issued by the World Health Organization (WHO), the European Union, as well as other travel advisories of private origin, namely the ones issued by private bodies of the Tourism, like tour operators, travel organizations etc. (Mylonopoulos-Moira \& Kikilia, 2014).

\section{Travel Advisories' Categorization}

The travel advisories of state origin influence more the citizens as long as it concerns their decisionmaking about travelling or not, due to the fact that, in theory, they are more precise, objective and mindfully issued. Furthermore, the same characteristics apply to the travel advisories issued by international organizations. A travel advisory's issue can refer to either safety or health issues

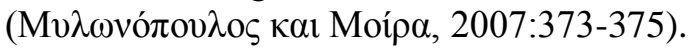

[1] The risks related to the travelers' safety are either human-induced or of natural origin.

\footnotetext{
1 In Greece travel advisories, as well as information concerning travelers' health issues in general, are redistributed by the Hellenic Centre for Disease Control and Prevention (HCDCP) of the Ministry of Health. see Hellenic Centre for Disease Control and Prevention, at http://www.keelpno.gr/
} 
The human-induced risks may originate from the social/political status (Norton, 1987:30-33), the social conditions of the country of origin (Ryan, 1993), the intermediate stops and the host regions (increased criminality, robberies, attacks, murders, bomb attacks, hostage-takings etc.). They can be grouped as follows:

a) According to the geographical criterion, that means to refer to certain broader geographical areas that go beyond the borders of a state (for example, piracy in the maritime region of South-East Asia). Apart from that, the dangers may also refer to a country as a whole (for example, Afghanistan), to be limited to a bounded region within a state, for example, the region of Chiapas in Mexico (Moípa, 2001:151), or the region of the north Sinai Peninsula in Egypt (FCO, 2015) or, finally, certain disadvantaged districts of urban centers like, for example, of Rio de Janeiro, Moscow, New York etc.

b) According to the social criterion, that means to be attributed to antisocial behaviors and to increased criminality observed, especially against the tourists, for example thefts, robberies, murders, rapes, racism etc.

c) According to the political criterion, that means to be attributed to terrorist threats or terrorist actions due to political, religious or other reasons. At this point, the example of Sri Lanka should be mentioned. There, in 1996, the Tamil rebels assaulted a train. This resulted to the death of 70 people, while 600 people were injured. After that, the former announced that they believe tourism is an "economic target". As a result, the country is considered to be an insecure tourist destination (Moípa, 2000:175). Another similar example is that of the massacre in Luxor that caused the containment of touristic flows towards Egypt (Moípa, 2001:39).

d) According to the geopolitical criterion, that means to result from a country's general political and economic situation like, for example, the political status instability, civil wars, strong minorities reactions, a status that does not favor tourism etc. However, similar risks may also result from the general political and economic situation of a broader region, like, for example, regions in Syria and the Russian Federation.

The risks of natural origin come from the natural environment of the place of destination. These risks can be categorized according to various criteria.

a) According to the geological criterion these risks may come from earthquakes like, for example, in Japan or to originate from volcanic activity, like, for example, in Indonesia or Iceland.

b) According to the environmental criterion these risks may come from the natural environment and the particular set of the host state's climatological circumstances, like, for example, typhoons, floods, storms, drought etc.

[2] The underlying risks concerning the travelers' health may originate from contagious diseases that may develop to epidemics or pandemics and may be attributed to bad living conditions, no respect of the hygiene conditions, lack of health insurance, lack of organization concerning the rapid treatment of medical emergencies like, for example, malaria or typhoid fever in Africa or Asia, dysentery and

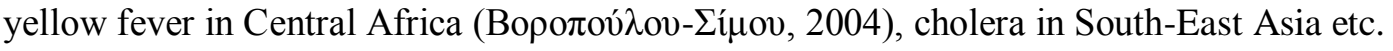

The content of the travel advisory reflects the risk level that the travelers tackle at their destination place, as this is estimated by each country. So, travel advisories are not presented in a single way. Many countries systematically issue travel advisories. As a matter of fact, these countries retain relevant websites in order to directly and rapidly inform anyone interested. In particular:

Great Britain: In general, British travel a lot and all over the world. The departures' number amounted to 58.510.000 in 2013 (The World Bank, 2015). The Ministry of Foreign Affairs of Great Britain retains a website which provides information and travel advisories (GOV.UK, 2015). The country uses three kinds of advices: (a) information about the current guidelines before travelling highlighted in green color, (b) advices against all but essential travel highlighted in orange color and (c) advises against all travel highlighted in red color.

France: The Ministry of Foreign Affairs of France uses a color-coding warning system (France Diplomatie (2015). So, green color is applied to normal situations that require simple alert, the yellow one means high alert for risks related to climatic factors, petty thefts usual to tourists, controlled health risks and, in general, risks that every country's tourists tackle. On the contrary, the orange color 
means that a country's visitation is generally discouraged, apart from reasons involving business or family. The red indication means total discouragement of travelling to a country or a broader region. At this point, it should be noted that no country is of no risk at all as long as it concerns the terrorist attacks.

Spain: Spain issues travel advisories by specific range, provides information about each country under the general indication Latest Updates (Ministerio De Asuntos Exteriores y De Cooperatión, 2015) and makes suggestions if necessary.

Germany: Germany retains a relevant website on which information about each country is published (Auswaertiges-amt, 2015). As long as it concerns the travelers' safety, Germany's advisories are categorized as follows: (a) advisories informing about the laws and each country's institutional framework in general, health issues, criminality or issues related to customs fraud. This information is regularly reviewed and updated, (b) advisories referring to specific dangers that the travelers might have to deal with. These advisories can recommend to either avoid travelling if not necessary or, even, to cancel any travel. This information is also reviewed and updated regularly, (c) advisories recommending to avoid travelling to a country. These advisories are issued when there are high probability risks in a country or a region, (d) warnings scarcely issued. In this case, German citizens are called to abandon a country they have already visited.

The Netherlands: The Netherlands keeps a four-step scale in combination with a color-coding system concerning the travel advisories it issues (Government of the Netherlands, 2015). The first level (green color) refers to non specific safety risks, the yellow shows that the travelers should be on guard due to risks regarding their safety; the orange suggests travelling somewhere only if necessary, while the red one suggests not travelling somewhere at all.

Finland: Finland retains a website in order to provide information about all the countries. This information (Ministry for Foreign Affairs of Finland, 2015) is updated every time there are changes made, or a crisis or certain incidents occur that may affect its citizens' lives. There is no information rating.

Canada: The country follows the four-step scale system travel advisories, which starts from the usual precautionary measures and extends to the recommendation to cancel a travel (Government of Canada, 2015). The Canadian Ministry of Foreign Affairs highlights the fact that every person is solely responsible for deciding on whether to travel or not.

Australia: Australia, in order to categorize its travel advisories, uses a combination of a four-step scale system and a system of color coding (Australian Government / Department of Foreign Affairs and Trade, 2015). The first level refers to normal safety precautions that should be taken during a travel (green color). The last level refers to the recommendation to avoid a travel or, even, to cancel it (red color). Furthermore, in every travel advisory a chart is introduced so that the risk level can be defined at a single glance. In some travel advisories there are more than one chart, in case different risk levels are recorded, according to the region. Finally, clarifications on issues relevant to criminality, money and valuable objects transfer are also given, along with recommendations for parents travelling with their children.

USA: The number of the American travelers reached 61.569.000 in 2013 (The World Band, 2015). In order to ensure the safety of its citizens during their travel, the USA presents two-level recommendations (US Department of State, Bureau of Consular Affairs, 2015), the Travel Alerts and the Travel Warnings. In the case of the Travel Alerts, the advisory is issued when short-term situations that might be dangerous occur, like, for example, an election period that might lead to demonstrations, strikes and convulsions in general, an epidemic, like, for example, the development of H1N1 or, finally, indications for a probable terroristic attack. However, at this point, it should be noted that the advisory is retracted as soon as the risk disappears. The Travel Warnings are issued in situations like state fragility, a civil war, violent crimes and frequent terrorist attacks. In this case, the citizens are asked to examine the likelihood of not travelling. These advisories are in force until the situation is altered, while they may be valid for years.

Japan: The Japanese travel all over the world and they are particularly interested in issues related to their personal safety, as well as in safety and health issues during their travel. At this point, it is important to mention that the number of Japan citizens who travelled abroad in 2014 amounted to 
16.902.868 (Japan Tourism Marketing Co, 2015). The Japanese government issues travel advisories categorized into four levels ${ }^{2}$ (MOFA, 2002). A travel advisory of level four suggests immediate departure from the country.

Russian Federation: Russia is a relatively new tourism market. Russians travel all over the world and, according to the relevant data, the number of departures from this country in 2013 amounted to 54.069.000 (The World Bank, 2015). The Russian Foreign Affairs Ministry retains a webpage (Department of Crisis Management Center/Ministry of Foreign Affairs of Russia, 2015) through which it provides advices and recommendations to the citizens, so that they are able to tackle certain incidents that may occur during their travel. At the same time, through the Ministry's Crisis Management Centre, information about all the countries is provided. Furthermore, news relative to each country's incidents and warnings about dangerous situations are published. If a country's situations demands particular attention, the webpage will be highlighted in red.

From the information given above, the lack of unity regarding the travel advisories' categorization becomes obvious, since differences are observed in the terminology, the risk levels as well as the risk's content, description and interpretation. Furthermore, the color marking differs from country to country.

The large number of the travel advisories as well as the observed differences in their categorization and severity may lead to imprecise, complex and non-harmonized information (Gaillard, 2003) that often confuse the travelers, paralyze the tourism industry and, finally, cause huge financial and social damage. As a matter of fact, according to the APEC, the main problem does not seem to be the travel advisories' issue, but the fact that they usually remain in force for a period longer than the critical one (APEC, 2003:3). One more serious problem is in the way the media manage the travel advisories (APEC, 2004:18-19) since the former tend to present the Disaster Myth (Faulkner, 2001:141) and to over-dramatize the chaotic situation often caused by such crises.

\section{The CaSe of Greek ECONOMIC Crisis}

\subsection{Methodology}

In order to investigate the way that the Greek economic crisis, which led to the closure of the banks and the limits imposed on cash withdrawals, was confronted, the authors searched the travel advisories issued by the states that consist important sources of tourists for the country. These states often issue travel advisories and retain a relevant website.

A research was performed in the relevant web pages which, in their majority, are operated by each country's competent Ministry of Foreign Affairs. After that, it was recorded whether there were travel advisories or simple information from each country. Finally, the relevant advices given for Greece, referring to the critical period between July and August 2015, were also searched and studied.

\subsection{Findings and Discussion}

\subsubsection{Ministries' of Foreign Affairs Websites}

After the onset of the Greek economic crisis in July 2015, the closure of the Greek banks and the limits imposed on cash withdrawals, the tourists' heading to Greece countries of origin issued advisories. The following information is indicative:

Great Britain: In this relevant to Greece webpage the usual information concerning the limits on the use of cards and cash were found.

France: The system was green for Greece and referred to the problems that had arisen from the application of the capital controls. Furthermore, the information that a number of merchandisers denied to accept a card as a means of payment and, instead, asked for cash only was also highlighted. Finally, the possibility of lack of medicine due to problems in goods import was also noted.

Spain: Spain's recommendation referring to Greece was mild. According to it, no specific limitations on travelling to Greece were mentioned. Due to the recent limits imposed on the financial and banking

\footnotetext{
${ }^{2}$ Japan's travel advisories were reformed in April 2002 and since then they involve five grades instead of four and refer to individual travelers, instead of tourist packages. The travel advisories are issued in the Japanese language (MOFA, 2002).
} 
system, the citizens visiting the country were advised to carry alternative means of payment, like, for example, cards and cheques, as well as cash, so that they would be able to cover everyday expenses. However, it was highlighted that no problems in the use of Spanish debit and credit cards in the transactions were met, apart from some difficulties in cash withdrawals due to the ATMs money depletion. Finally, the possibility of lack of medicines due to problems in goods import was also noted.

Germany: As long as it concerns Greece, no specific advisory was issued. In the relevant webpage general information about the country and the limits imposed on the use of cards and cash was mentioned.

The Netherlands: The country did not issue a travel advisory for Greece. The citizens travelling to Greece were only advised to carry cash.

Finland: The country did not issue a specific travel advisory for Greece, just updated the information given and advised the citizens travelling to Greece to carry cash and to be aware of the limits imposed on the use of cards.

Canada: Canada issued a travel advisory for Greece on July $30^{\text {th }} 2015$, which was referring to the usual necessary precautionary measures that the citizens travelling to Greece should take.

Australia: Australia issued a travel advisory referring to the economic crisis in Greece on July $20^{\text {th }}$ 2015 , in order to inform the citizens travelling to Greece about the use of cards and cash and suggested the usual necessary precautionary measures. Apart from that, the other information given was similar to the one referring to the other countries.

USA: There was no travel advisory issued referring specifically to Greece. The usual information about the demonstrations and strikes that take place in the country found in the website was filled in with information about the capital controls. The same information was also filled in the website of the Embassy of the US in Athens ${ }^{3}$.

Japan: After the closure of the banks and the capital controls, Japan just advised citizens travelling to Greece to carry cash and cards.

Russian Federation: A color indication of risk was found for Greece, but without any specific reference to the risk's content.

From the information given above, it becomes obvious that the countries did not consider the capital controls and the limits imposed on cash withdrawals in Greece as important to their citizens-travelers. So, in general, they did not issue any particular advices apart from the usual ones.

\subsubsection{The Role of the Mass Media}

It became obvious that the states did not consider the capital controls and the limits imposed on cash withdrawals in Greece as important to the travelers and, in general, they did not issue any particular advices apart from the usual ones. However, it is of interest to take a look at the way the media presented the issue. At this point, it is important and must be stressed the fact that the media often tend to overemphasize the risk they trace in travel advisories (APEC, 2004:2-3, 18-19) and that way they magnify the obstacles anyway imposed on tourism development by travel advisories issue

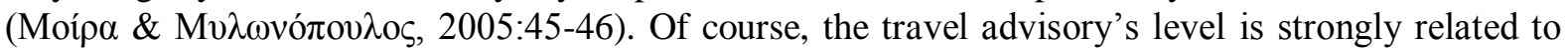
whether the incident (for example terrorist attack, climatic events etc.) has resulted to affected citizens.

\subsubsection{The Greek press}

The print and electronic media in Greece used, in majority, as a heading the phrase "Travel Advisory" with the strong feelings the latter provokes. So, the authors have found the headings using the term travel advisory often accompanied by other critical comments like:

- British provocation: Travel advisory about ATMs closed in Greece.

- England issues a travel advisory about the tourists in Greece, too.

${ }^{3}$ Embassy of the US in Athens (2015). In http://athens.usembassy.gov/demonstrations3.html 
- After Germany and Belgium, England also informs-warns its citizens on holiday in Greece.

- SHOCK IN TOURISM. Travel advisory of 7 countries: In case you go on holiday to Greece, carry cash!

- "Domino" of travel advisories for Greece after the latest news.

- One after another the countries issue travel advisories for Greece.

- BOMB FROM AUSTRALIA: TRAVEL ADVISORY ISSUED WARNING ABOUT... BANK PROBLEMS!!!

The authors mention that the term "travel advisory" is used to describe either serious incidents or simple advices. This situation obviously misleads the public, since the latter does not know whether a country issues travel advisories indeed or simply advises the citizens.

As a matter of fact, simple information like, for example, the one given by Great Britain for Greece is often characterized as travel advisory. At this point it should be mentioned that the term affects negatively, since it is indiscriminately used to describe terrorist attacks, like, for example the ones in Morocco and Tunisia, as well as simple incidents of robberies.

Furthermore, a great number of headings that cause fear to the travelers are unrealistic. A clear example is a newspaper ${ }^{4}$ that on June $28^{\text {th }}$ published an article with the following heading "In case you go on holiday to Greece, carry cash! The first problems in Greek tourism have already arisen, since the official authorities of seven countries warn their citizens visiting Greece about the situation here and advise them to carry cash... ... ... The article mentioned that Poland, Germany, Great Britain, the Netherlands, Finland, Belgium and Sweden had issued travel advisories. However, from the analysis presented above, these countries just updated their web pages regarding the use of cards and cash in the country.

Furthermore, the article of another newspaper ${ }^{5}$ on May $30^{\text {th }} 2015$ with the following heading "BOMB FROM AUSTRALIA: TRAVEL ADVISORY WARNING ABOUT... BANK PROBLEMS!!!" should also be mentioned. The newspaper, then, attached a copy of Australia's webpage, in which the usual precautionary measures were mentioned in green color.

Similar was the article published on a newspaper ${ }^{6}$ on June $28^{\text {th }} 2015$ with the following heading "British provocation: Travel advisory about ATMs closed in Greece", while, in the page providing information about Greece, the usual information about the limits imposed on the use of cards and cash was simply mentioned.

\subsubsection{The foreign press}

From the study of the headings of the wide readability newspapers, the following come up:

In the journal Daily and Sunday Express on June $20^{\text {th }} 2015$, the following characteristic heading appeared: "Greece travel alert: Foreign Office to review advice \& warns tourists to prepare for worst". Characteristic, too, is the following warning of CNN on June $6^{\text {th: }}$ " "Latest travel advice for

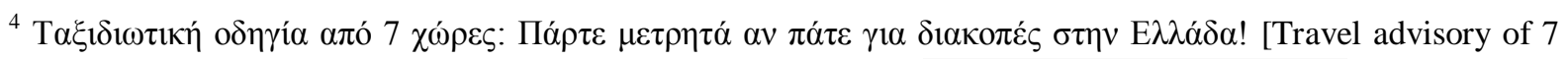

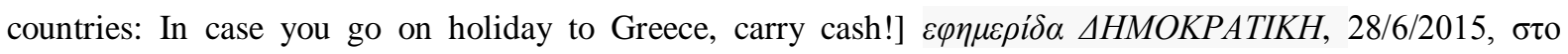
www.dimokratiki.gr/28-06-2015/taxidiotiki-odigia-apo-7-chores-parte-metrita-an-pate-gia-diakopes-stin-ellada/ ${ }^{5}$ BOMBA АПО THN AY TPAПEZIKO ПРОВ $\Lambda$ HMA!!! [BOMB FROM AUSTRALIA: TRAVEL ADVISORY ISSUED WARNING

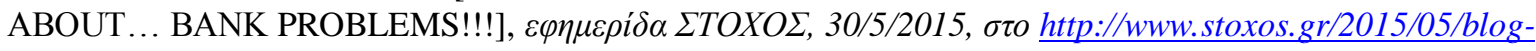
post_4277.html

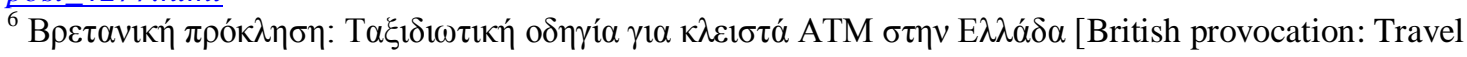
advisory about ATMs closed in Greece], 28/6/2015, $\sigma \tau$ h http://www.hellas-now.com/2015/06/blogpost_526.html\#sthash.E5N7Xmpr.dpuf

${ }^{7}$ Sykes, S. (2015). Greece travel alert: Foreign Office to review advice \& warns tourists to prepare for worst, Jun 20, 2015, Daily and Sunday Express, In http://www.express.co.uk/news/uk/585794/Greece-economic-crisiseuro-eurozone-tourists-holiday-Foreign-Office
} 


\section{The Travel Advisory as an Obstacle to Travel and Tourism. Case Study-The Greek Economic Crisis}

tourists heading to Greece ${ }^{8}$, as well as the heading of the International Business Times: "Travelling to Greece? Use these 5 tips to avoid holiday catastrophe ${ }^{9,}$.

Finally, The Guardian presented many headings referring to the Greek economic crisis, but without mentioning any travel advisory. These headings either highlighted the problem of liquidity shortage and suggested the travelers to carry cash, cards and, generally, various means of payment or, in the contrary, they stressed the chance for cheap holidays in Greece, while, at the same time, they mentioned that travelling to Greece could help the country recover from the crisis ${ }^{10}$.

Likewise, The Independent used benign headings, avoiding the use of the term travel advisory. In general, the headings raise questions and thoughts ${ }^{11}$, while the content of the relevant articles mainly aimed to provide guidance concerning alternative methods of payment, without trying to prevent the readers to visit Greece.

Spanish and French newspapers seem to have followed the same path, providing information and advices concerning the use of cash, credit and debit cards ${ }^{12}$. The following headings that prevailed in June 2015 are indicative:

- Summer holidays in Greece. Should we take measures?

- Should we go on holiday to Greece?

- 7 secrets concerning our holidays in Greece.

- What should I know in case I go on holiday to Greece?

The relative reports found in German newspapers were similar ${ }^{13}$.

\footnotetext{
${ }^{8}$ Tejada, M. and Neild, B. (2015). Latest travel advice for tourists heading to Greece, $C N N$, July 6, 2015, In http://edition.cnn.com/2015/07/06/travel/latest-travel-advice-for-tourists-visiting-greece/

${ }^{9}$ Lanktree, Gr. \& Schram, B. (2015). Travelling to Greece? Use these 5 tips to avoid holiday catastrophe, June 22, 2015, International Business Times, In http://www.ibtimes.co.uk/travelling-greece-use-these-5-tips-avoidholiday-catastrophe-1507374

${ }^{10}$ Keenan, St. (2015). How your Greek summer holiday can help Greece, The Guardian, 22/6/2015, In http://www.theguardian.com/travel/2012/jun/22/greek-summer-holiday-save-greece

Butler, Sara (2015). Tourists in Greece warned by Foreign Office banking services may be limited, 28/6/2015, The Guardian, In http://www.theguardian.com/world/2015/jun/28/tourists-greece-warned-foreign-officebanking-services-limited

Collinson, P. \& Osborne, H. (2015). How the Greek financial crisis could affect your holiday plans, 29/6/2015, The Guardian, In http://www.theguardian.com/money/2015/jun/29/greek-financial-crisis-holiday-plansholidaymakers-difficulties

Bowes G. (2015). Advice to travellers planning holidays in Greece and Tunisia, 04/7/2015, The Guardian, In http://www.theguardian.com/travel/2015/jul/04/travel-advice-planning-holidays-greece-tunisia

${ }^{11}$ Should holidaymakers worry about the Greece crisis? THE INDEPENDENT, 19/6/2015, In

http://www.independent.co.uk/travel/news-and-advice/should-holidaymakers-worry-about-the-greece-crisis10331580.html
}

Moodley, K. (2015). Greece travel advice Q\&A: Tourists urged to bring cash not cards on holiday, THE INDEPENDENT, 29/6/2015, In www.independent.co.uk/travel/news-and-advice/greece-travel-advice-qatourists-urged-to-bring-cash-not-cards-on-holiday-10351922.html

Calder, S. (2015). Travel to Greece: Should holidaymakers be anxious? THE INDEPENDENT, Tuesday 16 June 2015, http://www.independent.co.uk/incoming/travel-to-greece-should-holidaymakers-be-anxious10324105.html

12 Lunar, E. (2015). Siete consejos para viajar a Grecia, La Razón.es, 08 julio 2015, http://www.larazon.es/viajes/siete-consejos-para-viajar-a-grecia-KB10220749\#.Ttt1rtSdL80yBbh

Morice, L. (2015). Faut-il partir en vacances en Grèce ? 30-06-2015, L'obs, http://tempsreel.nouvelobs.com/lacrise-grecque/20150629.OBS1717/faut-il-partir-en-vacances-en-grece.html

Laurence Le Dren Vacances en Grèce: faut-il prendre des précautions? Notre temps.com, 15 juillet 2015, http://www.notretemps.com/droit/vacances-grece-quelles-precautions,i88634

${ }_{13}$ Krise in Griechenland: Banken zu, Auszahlungen begrenzt - was das bedeutet, 29/6/2015, Der Spiegel, http://www.spiegel.de/wirtschaft/soziales/griechenland-banken-geschlossen-was-bedeutet-das-a-1041098.html Hasnain Kazim (2015). Touristen in Athen: 500 Euro aus dem Automaten? Geht doch, 03/7/2015, Der Spiegel, http://www.spiegel.de/reise/europa/touristen-in-athen-griechenland-als-reiseziel-a-1041979.html 
From the reports presented above it becomes clear that the foreign press did not particularly examine whether travel advisories referring to Greece had been issued or not. Besides, whenever relevant reports appeared they were mainly given for information, and the term travel advisory was only exceptionally used. In conclusion, it seems that the foreign print and electronic media managed the issue in a different way and with less "scaremongering" in comparison to the Greek press.

\section{ASSESSMENTS - Critical APPROACH}

Any economic activity requires a safe developmental environment. The tourism sector is a particular case, due to the fact that it is extremely vulnerable to every type of insecurity causing fear to the travelers. A travel advisory's issue often has negative effects on tourist activity and becomes a

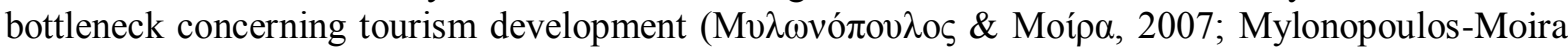
$\&$ Kikilia, 2014). As a matter of fact, these effects become more serious in the case that the state's economy is strongly related to either the tourism sector in general or a concrete tourism market ${ }^{14}$.

A travel advisory's issue removes, in fact, the unobstructed touring founded by the Manila's Declaration on World Tourism (OMT-WTO-BTO, 1980) and the Final Act of the Conference on Security and Co-operation in Europe in 1975 (Conference on Security and Co-operation in Europe, 1975), the Code of Tourism Rights (WTO, 1985), the Hague Declaration on Tourism (WTO, 1989) as well as the Code of Ethical Tourism (WTO, 1999; WTO, 2001).

The World Tourism Organization has, on very many occasions, pointed out the problem of the travel advisories' issue. The Organization's Secretary-General (Frangialli, 2004, In Mylonopoulos, Moira \& Kikilia, 2014) has stressed the fact that governments must collaborate with the international travel industry, so that the travel advisories will go hand in hand with the International Code of Ethics. The Code of Ethics refers to the obligations of the tourism bodies and the governments, which have the right and the duty, especially during a period of crisis, to inform the citizens about the difficult situations or even the danger they might face travelling abroad. However, it should be noted that the information given must not affect unfairly or in an extravagant way the tourism industry of the host countries and their entrepreneurs' interests. The recommendations should absolutely correspond to the situation's gravity and define exactly the geographical areas within which uncertain conditions prevail. Such advisories must be moderated or cancelled as soon as the repayment to normality allows it (WTO, 2001). The Code imposes the same obligations on the media and, particularly, on the specialized tourist press and the current electronic communication means. Specifically, the media must divulge truthful and well-balanced information for the facts and the situations that can influence the touristic flows and to provide the tourist services' consumers' precise and reliable information (WTO, 2001:7). This relates to the media's general obligation to adhere to the principle of impartiality, which is one of the fundamental ideals of the qualified journalists and the basic ethical dimension of the journalistic practice ( $\Delta \varepsilon \lambda \eta \gamma$ ióvvๆ, 2012:241).

Although the framework concerning the travel advisories' issue has indisputably been improved, in the states the latter refers to there still is disbelief regarding their issue's necessity. This disbelief focuses on the nature of the threat, the lack of geographical precision in relation to the threat, the failure to consult with the state that undergoes the advisory's effects ${ }^{15}$, the failure to revise or to timely call off the published advisory and the disagreement observed among the travel advisories issued by different countries and refer to the same destination. So, in many cases, it is imperative to manage the travel advisories in such a way that the travelers' safety will be maximized, while, at the same time, their negative effects on the travel and the tourism development will be minimized.

The management of the crisis caused by a travel advisory's issue in a way that its negative effects are minimized is, primarily, a competence of the state-receiver and of the bodies exerting tourism policy

\footnotetext{
${ }^{14}$ Gambia is a striking example. The dependence of the tourism sector on the British market mainly, the military crisis of 1995 as well as the travel advisories of Great Britain, led the British tourists to abandon the country. This resulted to a $73 \%$ decrease in the tourist flows coming from Great Britain and, finally, to the country's economy breakdown. At least 1000 jobs in the tourism sector were lost, while at least eight companies of the hotel sector stopped operating. (Sharpley G. and J. Sharpley, 1995, In Glaesser, 2003:158-159).

${ }^{15}$ The communication and information need between the country that issues the travel advisory and the one the latter refers to has repeatedly been highlighted by states-receivers of travel advisories, as comes up from the proposal of the state of South Africa, during the meeting of the UN Security Council on terrorism (UN, 2004:8).
} 
within it. The crisis management could only be accomplished within a carefully scheduled crisis management framework, which requires the cooperation of not only the public, but also the private tourism bodies. The existence of a crisis management special unit is imposed. The latter should be staffed by specialized personnel, and technical equipment, while it must also have the necessary infrastructure, as well as access to every information level and the media (Glaesser, 2003:192). Of similar importance is also the systematic collaboration and information exchange among the states that are involved in the crisis in any way, so that the travel advisory's negative effects will be

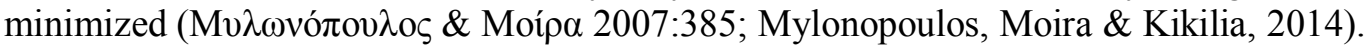

The past experience suggests that, in order to achieve effective reaction against the international crisis, stronger international collaboration and coordination of the tourism bodies' activity are needed. At the same time, the base, as well as the incentives of the travel advisories' issue should also be investigated (McKercher \& Kaye, 2004:718).

\section{CONCLUSION}

Tourism is a productive sector of the economy which, for a large number of states, suggests their basic source of wealth and development. The truth is that the travel advisories' issue overturns, in fact, the unobstructed touring. However, the international community is not allowed to impose obstacles on the tourism development using this measure. So, the plausible use of the travel advisories is imperative, so that the respectfulness of the communities and the destinations is ensured (Frangialli, 2003:2). At the same time, the travel advisories' accurate presentation from the media is absolutely necessary, since the latter can suspend a destination's touristic flows without this being necessitated by the travel advisory's spirit. Furthermore, the preparation of the host country tourism bodies, in order the latter to be able to appropriate tackle the travel advisories through the collaboration of the public and the private tourism sector, as well as their ability to schedule and implement an effective crisis management plan, are absolutely necessary.

\section{REFERENCES}

[1] APEC (2003). APEC Tourism Impediments. Study Stage 1. TWG 04/2001. Final Repory. Dain Simpson Associates, Sydney, Australia, February.

[2] APEC Tourism Working Group (2004). APEC Tourism Impediments Study. Stage 2. Final Report. (TWG/01/2004). Prepared for APEC Tourism Working Group Prepared by The Conference Board of Canada, Ottawa, Canada.

[3] Boniface, B. and Cooper, C. (2005). "The future geography of travel and tourism", in Boniface, B. and Cooper, C. (Eds) (2005). Worldwide destinations; The geography of travel and tourism, (fourth edition), Elsevier Butterworth-Heinemann, Italy, pp.476-488.

[4] Conference on Security and Co-operation in Europe (1975). art. 6. Co-operation in other areas, Promotion of Tourism. Final Act, Helsinki, 1 August. 6. Co-operation in other areas, Promotion of Tourism.

[5] Dupont, H.L. \& Steffen, R. eds, (1997). Textbook of Travel Medicine and Health. London, BC Decker.

[6] Faulkner, B. (2001). Towards a framework for tourism disaster management, Tourist Management, 22(2), p. 135-147.

[7] Frangialli, Fr. (2003). A Great Turning Point. Address to the European Tourism Forum by Secretary-General of the World Tourism Organization, Venice, Italy, 29 November.

[8] Gaillard, W. (2003). A Review of the Air Transport Industry, IATA Director, Corporate Communications, 4 August, In http://www.iata.org/pressroom/speeches/2003/2003-08-0401.html

[9] Glaesser, D. (2003). Crisis Management in the Tourism Industry. Butterworth-Heinemann.

[10] Mathieson, A. \& Wall, G. (1982). Tourism Economic, Physical and Social Impacts, London: Longman

[11] McKercher, B. - Kaye, Ch. (2004). The Over-Reaction to SARS and the Collapse of Asian Tourism, Annals of Tourism Research, 31(3), pp. 716-719.

[12] Mylonopoulos, D., Moira, P. \& Kikilia, Aik. (2014). "The travel advice as an inhibiting factor of tourist movement", International Scientific Conference "Tourism and Development", Faculty of Sport and Tourism from Novi Sad and Faculty of Tourism from Brežice, 6-7th November 2014 in Novi Sad, Serbia, Book of Abstracts, p. 20-21.

[13] Norton, G. (1987). Tourism and International Terrorism, The World Today, 43(2), pp. 30-33. 
[14] OMT-WTO-BTO (1980). Manila Declaration on World Tourism, Art. 3.

[15] Ryan, C. (1993). Crime, Violence, Terrorism and Tourism, Tourism Management, 14(3), pp. 173-183.

[16] Sharpley, G. and Sharpley, J. (1995). «Travel advice-security or politics?», In Security and risks in Travel and Tourism, Proceedings of the International Conference at Mid Sweden University, pp 168-182, In Glaesser, Crisis Management in the Tourism Industry. Butterworth-Heinemann.

[17] UN (2004). Threats to international peace and security caused by terrorist acts, S/PV.4921 (Resumption 1), 921st meeting, Thursday, 4 March, New York.

[18] UNWTO (2007). Tourism For International Understanding, Odyssey Media Group, 31 October, In http://www.odysseymediagroup.com/apn/Editorial-Associations.asp?ReportID=270507

[19] WHO (2003). International Travel and Health, Geneva.

[20] WTO (1985). Tourism Bill of Rights and Tourism Code.

[21] WTO (1989). The Hague Declaration on Tourism.

[22] WTO (1999). Approval of the Global Code of Ethics for Tourism, Resolution adopted by the UNWTO General Assembly A/RES/406(XIII), Thirteenth session, Santiago, Chile, September October.

[23] WTO (2001). Global Code of Ethics for Tourism Resolution adopted by the General Assembly, 21 December 2001, A/RES/56/212 Global Code of Ethics for Tourism.

[24] WTTC (2015). Travel and Tourism. Economic Impact 2015 World.

[25] Zuckerman JN. ed. (2001). Principles and practice of travel medicine, Chichester, J. Willey \& Sons.

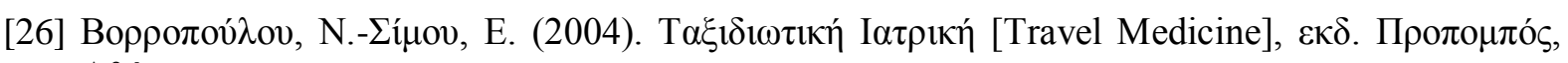
A $\theta$ íva.

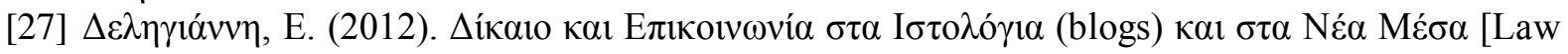

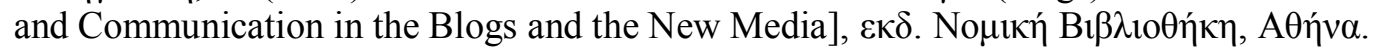

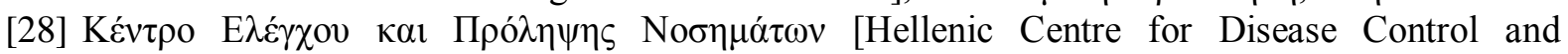
Prevention (HCDCP)], $\sigma \tau$ o http://www.keelpno.gr/

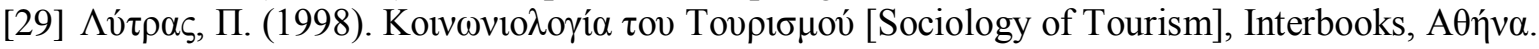

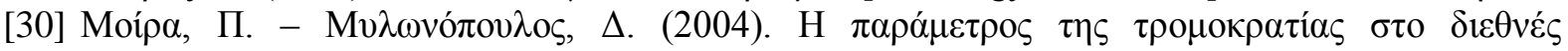

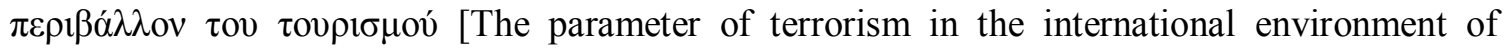

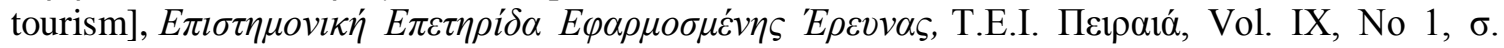
121-140.

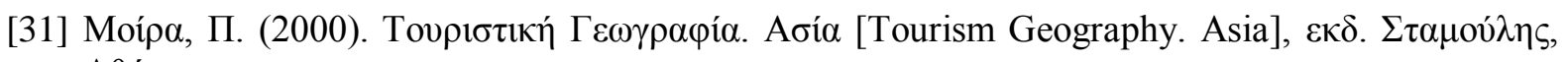
A $\theta \dot{n} v \alpha$.

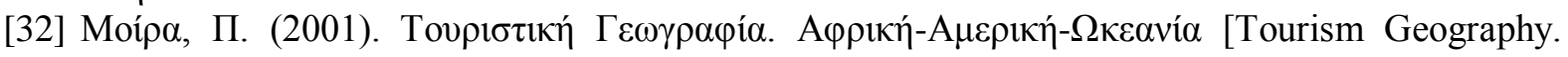

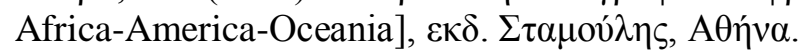

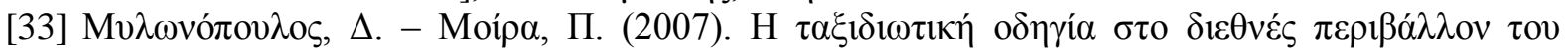

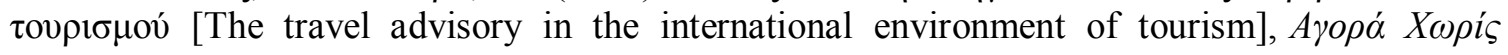

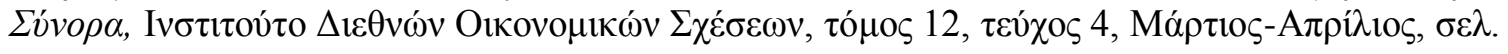
371-388.

\section{Print And Electronic Media}

[1] Bowes G. (2015). Advice to travellers planning holidays in Greece and Tunisia, 04/7/2015, The Guardian, In http://www.theguardian.com/travel/2015/jul/04/travel-advice-planning-holidaysgreece-tunisia

[2] Butler, Sara (2015). Tourists in Greece warned by Foreign Office banking services may be limited, 28/6/2015, The Guardian, In http://www.theguardian.com/world/2015/jun/28/touristsgreece-warned-foreign-office-banking-services-limited

[3] Calder, S. (2015). Travel to Greece: Should holidaymakers be anxious? THE INDEPENDENT, Tuesday 16 June 2015, http://www.independent.co.uk/incoming/travel-to-greece-shouldholidaymakers-be-anxious-10324105.html

[4] Collinson, P. \& Osborne, H. (2015). How the Greek financial crisis could affect your holiday plans, 29/6/2015, The Guardian, In http://www.theguardian.com/money/2015/jun/29/greekfinancial-crisis-holiday-plans-holidaymakers-difficulties 
[5] Keenan, St. (2015). How your Greek summer holiday can help Greece, The Guardian, 22/6/2015, In http://www.theguardian.com/travel/2012/jun/22/greek-summer-holiday-savegreece

[6] Lanktree, Gr. \& Schram, B. (2015). Travelling to Greece? Use these 5 tips to avoid holiday catastrophe, June 22, 2015, International Business Times, In http://www.ibtimes.co.uk/ travelling-greece-use-these-5-tips-avoid-holiday-catastrophe-1507374

[7] Laurence Le Dren Vacances en Grèce: faut-il prendre des précautions? Notre temps.com, 15 juillet 2015, http://www.notretemps.com/droit/vacances-grece-quelles-precautions, i88634

[8] Lo que debes saber si quieres ir de vacaciones a Grecia, ABC Viajar, 07/07/2015 http://www.abc.es/viajar/20150707/abci-consejos-viajar-grecia-201507061554.html

[9] Lunar, E. (2015). Siete consejos para viajar a Grecia, La Razón.es, 08 julio 2015, http://www.larazon.es/viajes/siete-consejos-para-viajar-a-grecia-B10220749\#.Ttt1rtSdL80yBbh

[10] Moodley, K. (2015). Greece travel advice Q\&A: Tourists urged to bring cash not cards on holiday, THE INDEPENDENT, 29/6/2015, In www.independent.co.uk/travel/news-andadvice/greece-travel-advice-qa-tourists-urged-to-bring-cash-not-cards-on-holiday$\underline{10351922 . \mathrm{html}}$

[11] Morice, L. (2015). Faut-il partir en vacances en Grèce ? 30-06-2015, L'obs, http:// tempsreel. nouvelobs.com/la-crise-grecque/20150629.OBS1717/faut-il-partir-en-vacances-en-grece.html

[12] Should holidaymakers worry about the Greece crisis? THE INDEPENDENT, 19/6/2015, In http://www.independent.co.uk/travel/news-and-advice/should-holidaymakers-worry-about-thegreece-crisis-10331580.html

[13] Sykes, S. (2015). Greece travel alert: Foreign Office to review advice \& warns tourists to prepare for worst, Jun 20, 2015, Daily and Sunday Express, In http://www.express.co.uk/news/ uk/585794/Greece-economic-crisis-euro-eurozone-tourists-holiday-Foreign-Office

[14] Tejada, M. and Neild, B. (2015). Latest travel advice for tourists heading to Greece, CNN, July 6, 2015, In http://edition.cnn.com/2015/07/06/travel/latest-travel-advice-for-tourists-visitinggreecel

[15] The World Bank (2015). International tourism, number of departures, In http://data. worldbank. org/indicator/ST.INT.DPRT

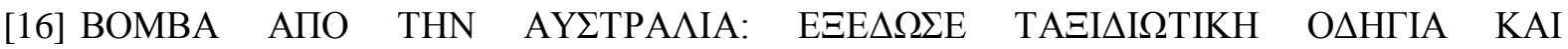
ПРОЕI $\triangle$ OПOIEI ГIA... TPAПEZIKO ПРОВ $\Lambda$ HMA!!! [BOMB FROM AUSTRALIA: TRAVEL ADVISORY ISSUED WARNING ABOUT... BANK PROBLEMS!!!], $\varepsilon \varphi \eta \mu \varepsilon \rho i ́ \delta \alpha$

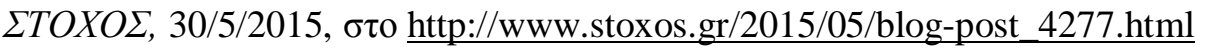

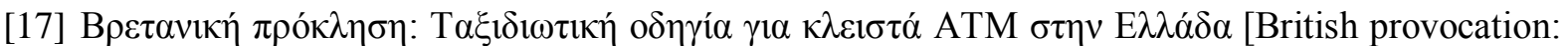

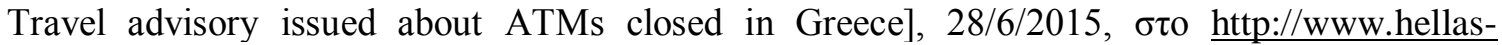
now.com/2015/06/blog-post_526.html\#sthash.E5N7Xmpr.dpuf

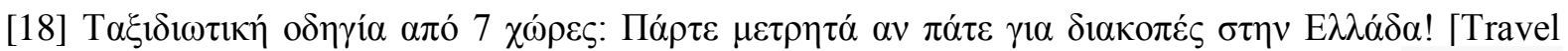
advisory of 7 countries: In case you go on holiday to Greece, carry cash!] $\varepsilon \varphi \eta \mu \varepsilon \rho i ́ \delta \alpha$ $\triangle H M O K P A T I K H, \quad 28 / 6 / 2015, \quad \sigma \tau \mathrm{o}$ www.dimokratiki.gr/28-06-2015/taxidiotiki-odigia-apo-7chores-parte-metrita-an-pate-gia-diakopes-stin-ellada/

\section{WEBSITES}

[1] Australian Government / Department of Foreign Affairs and Trade (2015). Travel Advice Explained, In http://smartraveller.gov.au/travel-advice-explained.html

[2] Auswaertiges-amt (2015). Aktuelle Reisewarnungen, In http://www.auswaertiges-amt.de/DE/ Laenderinformationen/01-Reisewarnungen-Liste_node.html

[3] Business Dictionary (2015). Travel Advisory, In http://www.businessdictionary.com/ definition/ travel-advisory.html

[4] Department of Crisis Management Center Ministry of Foreign Affairs of Russia (2015). In http:// sos.mid.ru/home

[5] Embassy of the US in Athens (2015). In http://athens.usembassy.gov/demonstrations3.html

[6] Foreign and Commonwealth Office (2015). Egypt Travel Advice, In https://assets.digital.cabinetoffice.gov.uk/media/55cf24e8e5274a5470000025/150812_Egypt_pdf.pdf 
[7] France Diplomatie (2015). Conseils par pays, In http://www.diplomatie.gouv.fr/fr/conseils-auxvoyageurs/conseils-par-pays/

[8] Gobierno De Espaňa / Ministerio De Asuntos Exteriores y De Cooperatión (2015). Recommend aciones de Viaje, In http://www.exteriores.gob.es/Portal/es/ ServiciosAlCiudadano/ SiViajas AlExtranjero/Paginas/RecomendacionesDeViaje.aspx\#AnchorG

[9] GOV.UK (2015). Foreign Travel Advice, In https://www.gov.uk/foreign-travel-advice

[10] Government of Canada (2015). Country travel advice and advisories, In http://travel.gc.ca/ travelling/advisories/faq\#whatdo

[11] Government of the Netherlands (2015). Reisadviezen, In http://www.rijksoverheid.nl/ onder werpen/reisadviezen/uitleg-kleurcodes

[12] Japan Tourism Marketing Co (2015). Historical Statistics - Japanese Tourists Travelling Abroad, Historical figures of the number of monthly Japanese departure by destination, In http:// www.tourism.jp/en/statistics/outbound/

[13] Ministry for Foreign Affairs of Finland (2015). In http://formin.finland.fi/ public/ default. aspx? nodeid=49399

[14] Ministry of Foreign Affairs of Japan (2015). In http://www.mofa.go.jp/ announce/announce/ 2002/4/0425.html

[15] Ministry of Foreign Affairs of Japan (2002). Press Conference 23 April 2002 \& Press Conference 27 September 2002, In http://www.mofa.go.jp/announce/press,

[16] US Department of State, Bureau of Consular Affairs (2015). Alerts and Warnings, In http:// travel.state.gov/content/passports/english/alertswarnings.html

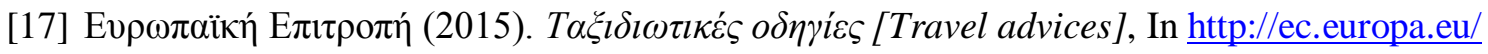
consularprotection/traveladvice el

\section{AUTHOR's BIOGRAPHY}

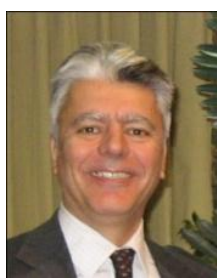

Dr. Dimitrios Mylonopoulos, holds a PhD in Public Law from Panteion University of Political and Social Sciences, Greece. He has studied at Democriteion University of Thrace, Panteion University, Harokopieio University, Economic University of Athens, National and Kapodistrian University of Athens and Hellenic Navy Academy. He holds BA degrees a) in Law, b) in Public Administration, c) in International and European Studies and d) in Communication and Mass Media. He also holds a) MSc in Applied Geography and Area Management , b) in Pedagogy, c) in European Studies, d) in Maritime Studies and e) in Promotion of Mental Health and Prevention of Mental Disorders. He has been teaching at higher education over the last 20 years. He is retired senior officer in Hellenic Coast Guard. He is currently Professor at the Department of Business Management at the Piraeus University of Apllied Sciences (Greece). He is also a Visiting Professor at the University of Patras, at Hellenic Army Academy, at Hellenic Naval Academy and at Hellenic Open University. He has published scientific books in the field of tourism and maritime issues and articles in international and Greek journals.

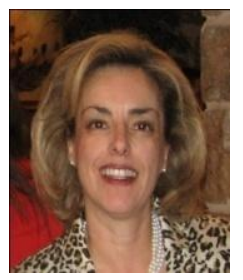

Dr. Polyxeni Moira, holds a PhD in Sociology from Panteion University of Political and Social Sciences, Greece. She has BA degrees a) in Public Administration, b) International and European Studies and c) Communication and Mass Media. She also holds an MSc in Regional Development and Pedagogy. She has been teaching at higher education over the last 12 years. She is currently a Professor at the Department of Tourism Industry Management at the Technological Education Institute of Piraeus in Greece. She is also a Visiting Professor at the University of Ioannina and the Hellenic Open University. She has published 12 scientific books in the field of tourism and articles in more than 20 international and Greek journals.

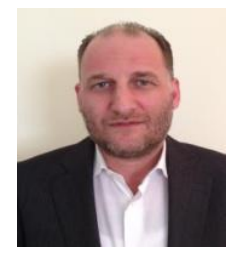

Dr. Aristides Papagrigoriou, holds a $\mathrm{PhD}$ from Harokopio Univeristy of Home Economics and Ecology "The Contribution of Innovation to Enterprenship. He has also a BA in Business Administrtaion from Priraeus University of Appliend Sciences and a MSc in Project Management from City University of Seattle Bellevue. He is currently a Lecturer on Management at Piraeus University of Applied Sciences/Department of Business Management 